\title{
Structural framework of the Wagad uplift and adjoining regions, Kutch rift basin, India, from aeromagnetic data
}

\author{
P R Radhika ${ }^{1}$, S P Anand ${ }^{1, *}$, Mita Rajaram ${ }^{1}$ and P Rama RaO ${ }^{2}$ \\ ${ }^{1}$ Indian Institute of Geomagnetism, Navi Mumbai, Maharashtra, India. \\ ${ }^{2}$ Andhra University, Visakhapatnam, India. \\ *Corresponding author. e-mail: aerospl@yahoo.co.uk
}

MS received 12 March 2019; revised 28 May 2019; accepted 4 June 2019

The Kutch sedimentary basin formed during the Late Triassic breakup of Gondwanaland is characterised by horst and graben structures consisting of several east-west trending uplifts surrounded by low-lying plains. The eastern part of the basin has a diverse landscape comprising the Wagad uplift, Banni plain, Island Belt uplift and the Rann of Kutch. This area is bounded by major faults like the South Wagad Fault (SWF), Gedi fault and the Island Belt Fault. The lineaments/faults present in the region at different depth levels and the propagation of these features through the different sedimentary layers are studied using the semi-detailed aeromagnetic data collected over the basin. The aeromagnetic anomaly map depicts several major E-W, NE-SW and NW-SE oriented lineaments/faults, which probably represent structural trends associated with different stages of evolution of this rift basin. Power spectral analysis of the differential reduced to pole magnetic data indicates the presence of four magnetic interfaces. The slopes identified from the 1D power spectra were used for designing matched bandpass filters for isolating and enhancing the magnetic signatures present within those interfaces. Different edge detection techniques were used to delineate the magnetic contacts/faults/lineaments present in those interfaces. In addition, we have computed the radially averaged power spectrum of 121 subset grids each with a dimension of $20 \mathrm{~km} \times 20 \mathrm{~km}$ from which three magnetic interfaces were delineated and compared with the stratigraphic sequence of the Wagad uplift and adjoining regions. A major NE-SW fault is delineated from this analysis and suggests that this fault has depth persistence as it dislocates the different magnetic interfaces. Integration with stratigraphic data suggests that this fault was formed prior to the deposition of Miocene Kharinadi formation. We have interpreted that this fault, forming the eastern limit of the Banni basin, might have formed during the passage of the Indian plate over the Reunion hotspot. Based on the results of the aeromagnetic data analysis and other published data, we propose a generalised evolutionary model for the study region.

Keywords. Aeromagnetic; Wagad uplift; power spectrum; depth to basement; lineament mapping.

\section{Introduction}

The Kutch basin located along the western most periphery of the Indian subcontinent is one of the earliest rift basins associated with the Late Triassic breakup of Gondwanaland. The origin and Published online: 27 July 2019 evolution of the Kutch rift basin are fairly well documented. This rift basin is characterised by highlands and plains which are the areas of uplifts and half grabens (Biswas 1987). The major uplifts are the Kutch Mainland uplift, Wagad uplift (WU) and Island Belt uplift (Patcham, Khadir, Bela and 
Chorar). The E-W trending half grabens preserve nearly a complete record of the sedimentary succession from the Mesozoic to recent (Biswas 2005), punctuated by several stratigraphic breaks. Even though this basin is located in the stable continental region about $500 \mathrm{~km}$ away from the Indian plate boundary, seismic activities are very common in this region (Mandal et al. 2009; Malik et al. 2017). After the devastating earthquake that occurred in 2001, the seismic events of the Kutch basin have been keenly monitored by the scientific community. The spatial-temporal patterns of the post-seismic activities clearly indicate the northward migration of the micro earthquakes from the epicentral region of the 2001 Bhuj earthquake (Mandal et al. 2009). The seismic activities have dramatically increased in the recent past in the eastern part of the Kutch basin where a large network of faults is present and are active. Lineaments/faults, their displacement and intersection are widely identified as one of the important reasons of continued earthquake activity in a given region (Singh and Singh 2005). In addition to seismic activity, fault intersection points are important features as they control intensive magmatism, volcanism, ore fields and deposits, and oil and gas fields. Hence delineation of lineaments/faults of varying scales is of paramount importance not only from a hazard point of view, but also in the exploration of natural resources. Aeromagnetic maps can effectively map lineaments/faults of different levels of any region (e.g., Grauch et al. 2006; Rajaram et al. 2006; Anand and Rajaram 2007; Rajaram and Anand 2014) and the near surface features can be co-related with those deduced from satellite imageries. Aeromagnetic method is a rapid and effective geophysical method that helps to reveal complete basement architecture and nature of intrusions, etc. especially in sedimentary basins. In addition to the mapping of major structures, the determination of sediment thickness is also very essential for the evaluation of any sedimentary basin. Previous analysis of the aeromagnetic data over the Kutch basin helped in delineating several lineaments that are otherwise masked by the Rann of Kutch and the depth persistence of mapped surface faults underneath the sediment cover (Radhika et al. 2017). In the present work, we have utilised the aeromagnetic data over the WU and adjoining areas. The objectives of the study are to identify and delineate the structures associated with the WU and adjoining areas, compute the depth of the different magnetic interfaces including the basement and also to delineate lineaments/faults associated with the different magnetic interfaces which might have played a crucial role in the evolution of the Kutch rift basin. We look for an evolutionary model of the study region by integrating the results of the analysis of the aeromagnetic data set with other published information.

\section{Generalised geology and tectonics}

Kutch is an E-W oriented seismically active pericratonic palaeo-rift basin located at the western extremity of India (Biswas 1987, 1999, 2005). The Kutch basin has evolved during the early stages of rifting between India and Africa in the Late Triassic/Early Jurassic period by the reactivation of primaeval faults in the Pre-Cambrian Delhi fold belt (Biswas 1987, 2005). During the Jurassic period, a part of the Tethys Ocean transgressed into the newly formed Kutch basin and the marine sedimentation caused the southward migration of the rifting. It was followed by sea regression and the deposition of thick delta wedge in the Early Cretaceous period which has ceased the rifting of Kutch (Biswas 1999). The basin has a unique asymmetric geometry having a tilt towards the south. The basin is delimited in the north by the Nagar Parkar fault and the south by the North Kathiawar fault. In the eastern side of the basin, a hinterland called the Radhanpur-Barmer basement arch restricts the rift extension, whereas on the western side, the basin merges with the continental shelf. The Kutch landscape is demarcated by highlands which are the uplifted areas and flatlands which are the basins between the uplifts (Biswas 1987). The uplifts are a rugged hilly terrain which exposes Mesozoic rocks and the lowlands are a vast spread of featureless plains covered by Holocene sediments. Figure 1 represents the generalised geology and tectonics of the Kutch rift basin redrawn from GSI (2001), Chandrasekhar and Mishra (2002) and Ngangom and Thakkar (2016), depicting the major structural elements and stratigraphic units. The black-dashed rectangular box demarcates the present study region. The major uplifts of the region are the Kutch Mainland uplift, WU and Island Belt uplift (IBU). The E-W trending major faults bounding these uplifts are the Kutch Mainland Fault (KMF), SWF and the Island Belt Fault (IBF). The basin contains several E-W to NW-SE trending major faults other than 


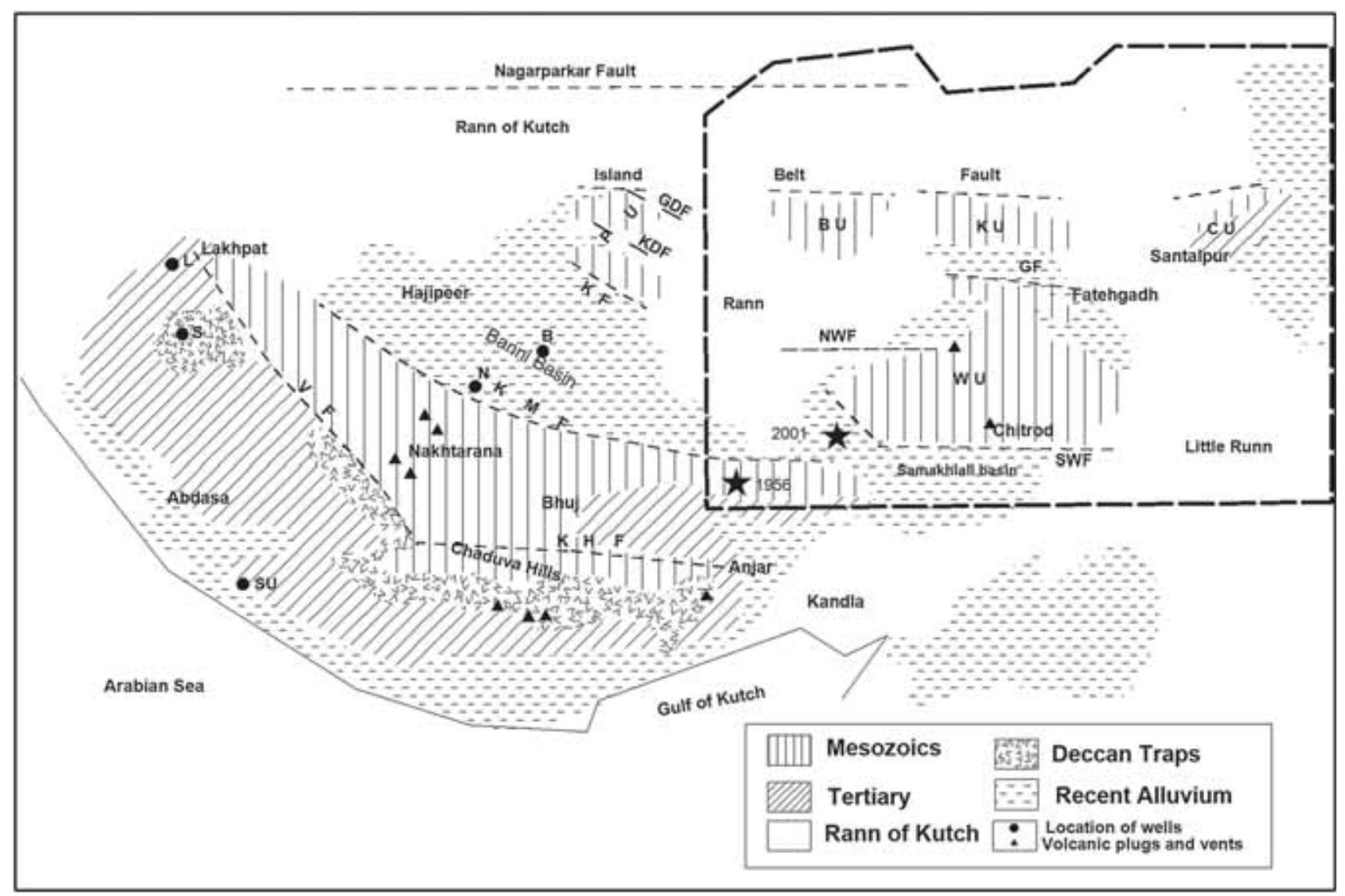

Figure 1. Geological sketch map of the Kutch rift basin redrawn from Biswas (1987), GSI (2001), Chandrasekhar and Mishra (2002) and Ngangom and Thakkar (2016): Dashed lines represent the major faults: KMF: Kutch Mainland Fault, VF: Vigodi Fault, KHF: Katrol Hill Fault, MH: median high, NWF: North Wagad Fault, SWF: South Wagad Fault, GF: Gedi Fault, KDF: Kala Dongar Fault, GDF: Gora Dongar Fault, KF: Khavda Fault. PU: Patcham uplift, BU: Bela uplift, KU: Khadir uplift, CU: Chorar uplift, WU: Wagad uplift. Black stars show the location of earthquake epicentres. Black triangles represent the locations of volcanic plugs, vents and intrusives. Black filled circles indicate the location of drilled wells, L: Lakhpat, Su: Sutri, N: Nirona and S: Sanadra. The black dashed rectangular box outlines the study area.

the uplift bounding faults, such as the Katrol hill fault, Vigodi fault, Banni fault and the Allah Bund fault (Biswas 1987).

The Wagad area which is on the eastern part of the basin is characterised by the WU to the north, Little Rann of Kutch to the west \& east and the Samakhiali basin (Karanth and Gadhavi 2007), an intrabasin zone bounded by the KMF and SWF, to the south. A fault system called the SWF bounds the broken WU on the south (Biswas and Khattri 2002; Mathew et al. 2006). The SWF is a steep southward dipping fault which is completely buried below the miliolite of aeolian origin and is marked by the contact between sheared Mesozoic rocks and Tertiary rocks and displaced at three places where it interacts with the transverse faults (Kothyari et al. 2016a; Maurya et al. 2017). To the north of WU, the Gedi fault marks the litho-tectonic contact between the upthrown Mesozoic sedimentary block and the downthrown Miocene sedimentary block (Maurya et al. 2013a, 2017; Kothyari et al. 2016b). The major part of the outcropping area in Wagad comprises the Mesozoic sediments ranging in age from Middle Jurassic to Lower Cretaceous and rest comprises Tertiary sediments. In the central and southern part of the Wagad, the Washtawa formation, the oldest stratigraphic unit in the WU, is exposed, which consists of shales, silty shales and sandstones. Towards the south and south-west of the region, sediment thickness increases, indicating subsidence and larger sediment accumulation (Mishra and Biswas 2009). The rocks of the Kanthkot formation, mainly comprising sandstones and shale, overlie the Washtawa formation. The lower Kanthkot formation contains ferruginous sandstones and is exposed at the northern range of the WU.

Towards the west and the north of the WU lie, respectively, the Banni plain and the Island Belt uplift. The Banni plain, often referred to as the 
Banni half graben and Banni footwall syncline, is a nearly flat but slightly undulating saline grassland which is bordered on the south by the KMF (Biswas 2005; Karanth and Gadhavi 2007; Chowksey et al. 2011; Sant et al. 2017). The IBU consists of four discontinuous uplifted landmasses where Mesozoic rocks are exposed. From the west to the east, these E-W trending en-echelon uplifts are Patcham (outside the study area), Khadir, Bela and Chorar (Malik et al. 2017; Singh et al. 2017). It is surrounded by the Rann of Kutch which is situated at a few metres above the sea level (Biswas 2005; Paul et al. 2008; Maurya et al. 2017). The northern margin of the Island Belt uplift is confined by the IBF system located further north covered by the Rann of Kutch sediments (Biswas 2005; Chowksey et al. 2010; Maurya et al. 2017; Sant et al. 2017). Generally, the Eastern Kutch Mesozoic sedimentary rocks comprise sandstones and shales. In the Banni region and the Great Rann and Little Rann regions, Tertiary rocks lie beneath the Holocene sediments and are exposed in the periphery of the uplifts. The Tertiary rocks are composed of clay-stones, siltstones, foraminiferal limestones, silty shales and calcareous sandstones (Maurya et al. 2013b). The Quaternary sediments are of aeolian, marine and fluvial origin.

\section{Data and methodology}

The semi-detailed aeromagnetic data over the Kutch Rift basin along NS lines spaced at 1-km interval at a flying height of $300 \mathrm{~m}$ with respect to topography collected by Alcock McPhar Geotech India (Pvt.) Ltd. on behalf of the Directorate General of Hydrocarbons was acquired by Indian Institute of Geomagnetism. The crustal magnetic anomaly map of the basin (Radhika et al. 2017) was subjected to differential reduction to pole (DRTP) (Cooper and Cowan 2005; Arkani-Hamed 2007) as the study region lies in relatively low magnetic latitudes (mean inclination $36^{\circ}$ ). The standard reduction to pole (RTP) operation is strictly valid at only a single observation point. When study areas are small (order of $100 \mathrm{~km}^{2}$ ), associated RTP errors caused by using only a single inclination and declination will be minimal as the Earth's magnetic field direction does not vary rapidly. However, for larger areas, as in the case of the present study area, these errors can be significant. To alleviate these errors, we have applied the differential reduction to the pole operator with appropriate magnetic inclination and declination, at each observation point, thereby accomplishing differential reduction (Arkani-Hamed 2007). The DRTP operator will place the anomalies directly over the causative sources assuming induced magnetisation alone is the causative source of anomalies. These DRTP data are subjected to different processing techniques (discussed below) for drawing meaningful inferences.

To enhance the high-frequency anomalies originating from shallow sources, a second vertical derivative (SVD) map was prepared. It is a powerful interpretive tool that can be used in the delineation of causative bodies and accurately locate changes in the magnetic field gradients (Peters 1949; Thomas 1951; Telford et al. 1990; Blakely 1995a, b). One of the major objectives of the aeromagnetic data interpretation is to quantitatively map the magnetic basement depth lying beneath the sedimentary cover. Depth to the source interpretation of magnetic data provides important information on basin architecture for petroleum and mineral explorations (Alagbe 2015). In the current study, the estimation of the depth to the top of the magnetic interfaces was carried out using statistical spectral analysis (Spector and Grant 1970). According to this hypothesis, it is assumed that the map of the magnetic field intensity over an area after the removal of the main geomagnetic component consists of the superposition of a large number of individual anomalies which are caused by several ensembles of blocks having various dimensions and magnetisations (Spector and Grant 1970; Blakely 1995a, b). From the logarithm of the radially averaged power spectrum versus wavenumber graph, one can identify linear segments, the slopes of which are proportional to the average depth to the top of the ensemble of source bodies (Blakely 1995a, b), with each linear segment representing sources lying at different depths. To generate maps representing average depths to the top of different interfaces, we have divided the whole region into several subset anomaly grids each with a dimension of $20 \mathrm{~km} \times 20 \mathrm{~km}$, with $50 \%$ overlap resulting in 121 blocks. The power spectra can then be used to design filters that will pass the anomalies with the desired spectral characteristics (Spector and Grant 1970; Cowan and Cowan 1993). Matched band-pass filtering is an effective way to separate magnetic anomalies arising from different depth layers. This particular filtering method uses the model parameters determined from the natural log of the power spectrum in 
designing the appropriate filter (Cowan and Cowan 1993; Blakely 1995a, b; Sheriff 2010).

To identify the magnetic contacts, faults and lineaments present in the different interfaces computed through power spectrum and matched bandpass filters, we have applied the edge detection techniques (Phillips et al. 2007) like Euler 3D, analytic signal and horizontal gradient magnitude (HGM). Edge detection is the process of finding the sharp discontinuities and locating the edges of a source body. Euler 3D is a reliable method in the rapid estimation of the depth and position of a large set of magnetic data (Reid et al. 1990). The analytic signal produces maxima at magnetisation contrasts and determines the edges of these contacts along with their depth of occurrence (Roest et al. 1992; MacLeod et al. 1993). When the source body is wider, the function will form a peak on the edges, and when the body is narrow, the peak will be directly over the centre of the body (Reid et al. 1990; Milligan and Gunn 1997; Ansari and Alamdar 2009). The total Horizontal Gradient Magnitude (HGM) is one of the simplest and fastest methods of edge detection, which demands only the calculation of two horizontal derivatives (Phillips 2000; Ndougsa-mbarga et al. 2012; Ngoh et al. 2017). HGM is useful in the demarcation of the horizontal location of the edges and also for the detection of the minimum and maximum source depths. The final lineament map is prepared after comparing the results of all these methods and the features that are common in all the three methods are considered for the final interpretation.

\section{Results and discussion}

The DRTP magnetic anomaly map (figure 2) shows a mixture of short, moderate and long wavelength anomalies that indicate the different depths of the source bodies. The long wavelength anomalies suggest the deeper depths of burial of the source bodies and the moderate and high-frequency anomalies indicate the presence of shallower source bodies. For a direct correlation, the mapped faults and other geologic units from figure 1 are superposed on this map (figure 2). The Banni basin region where the sediment thickness is larger reflects long wavelength anomalies whereas the Rann of Kutch region, the inaccessible salt marsh, exhibits moderate to short wavelength anomalies. The primary trend of the major magnetic anomalies (figure 2) is NW-SE towards the west (within the Banni basin), changing to EW in the

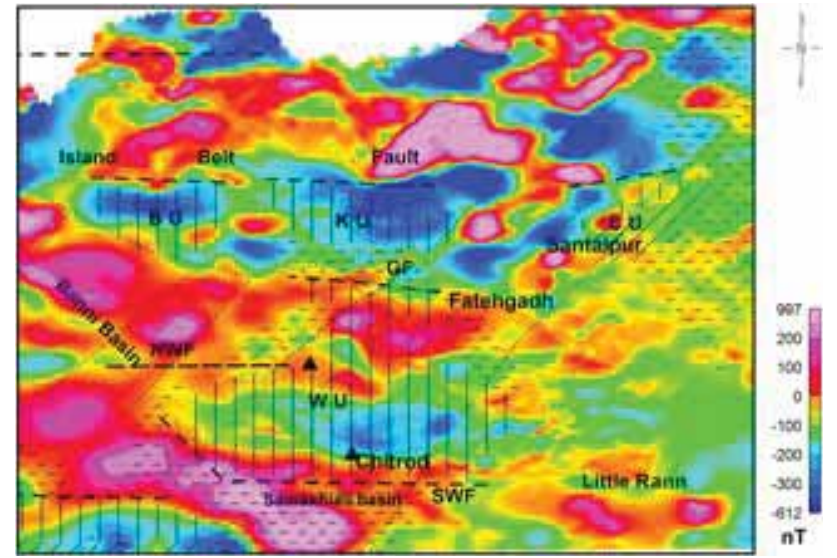

Figure 2. Differential reduction to the pole map of the WU and adjoining regions. Dotted lines show some of the interpreted lineaments from this map. Generalised geology and mapped faults from figure 1 are superposed. NWF: North Wagad Fault, SWF: South Wagad Fault, GF: Gedi Fault, BU: Bela uplift, KU: Khadir uplift, CU: Chorar uplift, WU:Wagad uplift (other abbreviations as in figure 1).

central part of the study area (WU) which is in accordance with the geological and tectonic structure of the region. In addition, the map exhibits several anomalies having NE-SW trends as well (marked by the dotted lines in figure 2). The anomaly amplitudes suggest moderate to highly magnetised rocks in the subsurface. The long to moderate wavelength anomalies depict high amplitudes. The topographic highs associated with the IBF show an inverse correlation with the high amplitude magnetic anomalies suggesting the possible presence of reversely magnetised magnetic rocks in the subsurface. In the WU area, there is lack of correlation with topography which suggests that moderately magnetised magnetic sources underlie the uplifted area.

Second vertical derivative (SVD) map enhancing short wavelength is shown draped on the digital elevation model (figure 3). The high-frequency anomalies produced by the localised near surface features are enhanced and the long wavelength anomalies associated with the deeper sources are diminished in this map. The Banni basin region where the long wavelength anomalies were prominent in the DRTP map is devoid of the anomalies in the SVD map indicating the source bodies are at a deeper level. The other interesting observation is the sudden change in anomaly frequency from west to east. Towards the west, within the Banni basin, the sources are at deeper levels where as the WU area is dominated by high-frequency/shallow level sources. Based on this change in short wavelength anomaly signatures, we place a NE-SW trending 

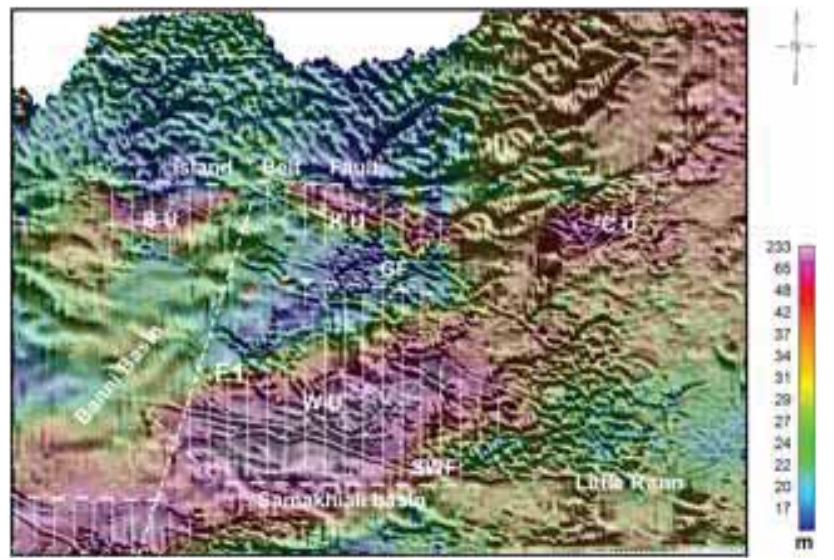

Figure 3. SVD map of the region depicting shallow sources draped on the digital elevation model. F1 represents the newly identified fault interpreted to be the eastern limit of the Banni basin where there is a change in the frequency of anomalies on either side. WNW to NW-SE high-frequency linear anomalies seen east of $\mathrm{F} 1$ represents the signatures of dykes within the WU. Abbreviations as in figure 1.

fault (F1) between the Banni basin and WU which appears to delimit the Banni basin towards the east. High-frequency anomalies representing signature of shallow-level causative sources are predominant towards the eastern side of this newly identified fault (F1 in figure 3). These short wavelength linear anomalies that are cutting across the WU can be correlated to the exposed and subsurface basic dykes (Mallik et al. 2008) suggesting intensive activity in this area. In addition, several short wavelength anomalies representing shallow-level sources are visible towards the north of the IBF, suggesting basement rocks at near surface level in this region.

\section{Depth estimation and matched filtering}

Depth to the top of the different interfaces for the whole study region was generated using the radially averaged power spectrum. The logarithm of the radially averaged power spectrum as a function of the frequency represented in figure 4 is further analysed, from which we could resolve four obvious linear segments with diverse slopes. The entire study region could be represented by four magnetic interfaces at the depths of $0.5,1.08,1.8$ and $4 \mathrm{~km}$. The depth estimates correspond to the whole region under study and hence represents the average from the Banni basin, the region above the IBF, WU and the region to the east of WU. The magnetic anomalies arising from different source depths can be effectively separated using the

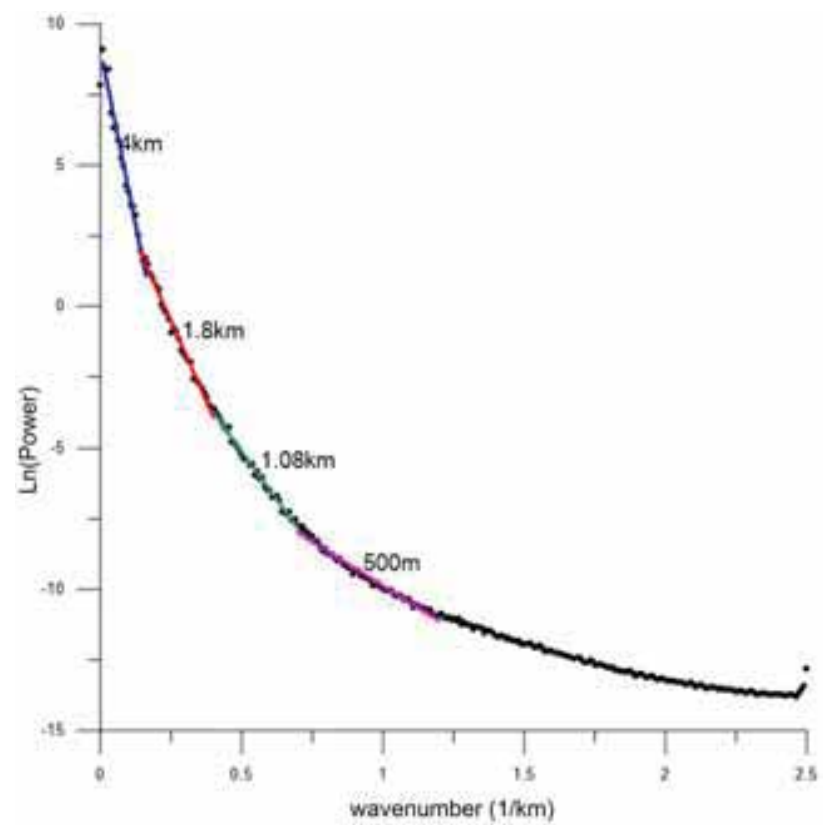

Figure 4. Radially averaged power spectrum of the DRTP map. The four magnetic interfaces are at depths 4, 1.8, 1.08 and $500 \mathrm{~m}$, respectively.

matched bandpass filtering method. In the present investigation, matched bandpass filtering was applied to the DRTP map for isolating and enhancing the magnetic anomalies originating from the causative source lying at depths of 4, 1.8, 1.08 and $0.5 \mathrm{~km}$, respectively, obtained from the radially averaged power spectrum of the main DRTP grid. The results of applying band pass filters are shown in figure $5(\mathrm{a}-\mathrm{c})$. Figure $5(\mathrm{a})$ illustrates the anomalous field from the long wavelength part of the spectrum. This layer contains magnetic anomalies caused by the deepest and broadest geological features representing the crystalline basement. The anomalies have a primary trend of NW-SE with secondary NE-SW imprints. This long wavelength anomaly map possesses similarities with the differential reduction to the pole map. The pattern of the anomalies appears to have a horst and graben structure. The anomaly from the second magnetic interface lying at the depth of $1.8 \mathrm{~km}$ (figure 5b) is distinctly different from the deepest interface where the long wavelength anomalies were prominent. The second interface represents the intermediate source anomalies. The figure depicts linear anomalies mainly in the NE-SW (above IBF) and NW-SE (below IBF) directions. The overprinting of the major anomalies present in the deepest layer is clearly evident in the second layer. By and large, the anomalies seen at this interface essentially outline the edges of the 
(a)

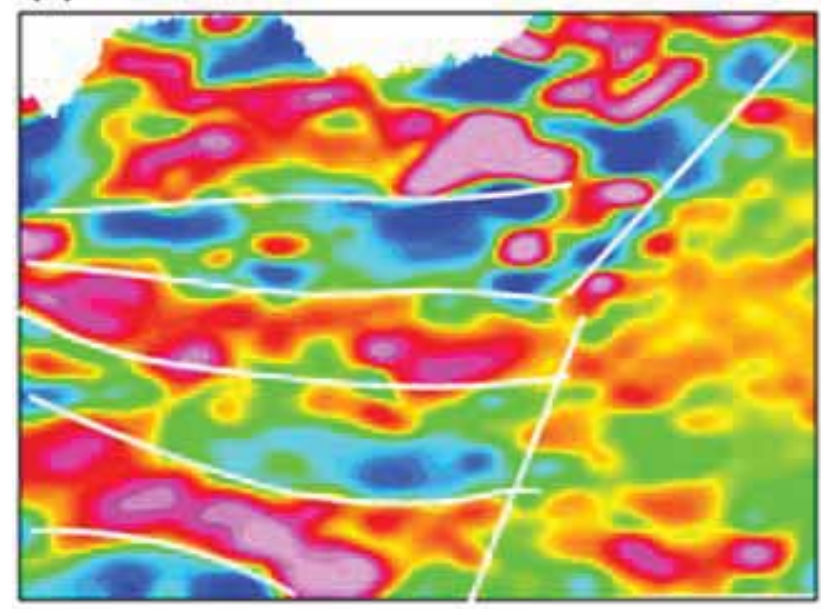

(b)

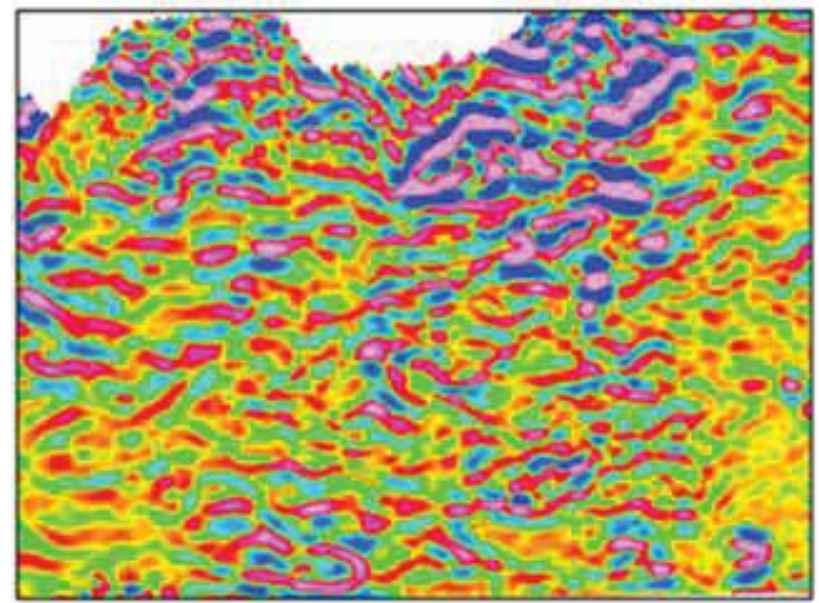

(c)

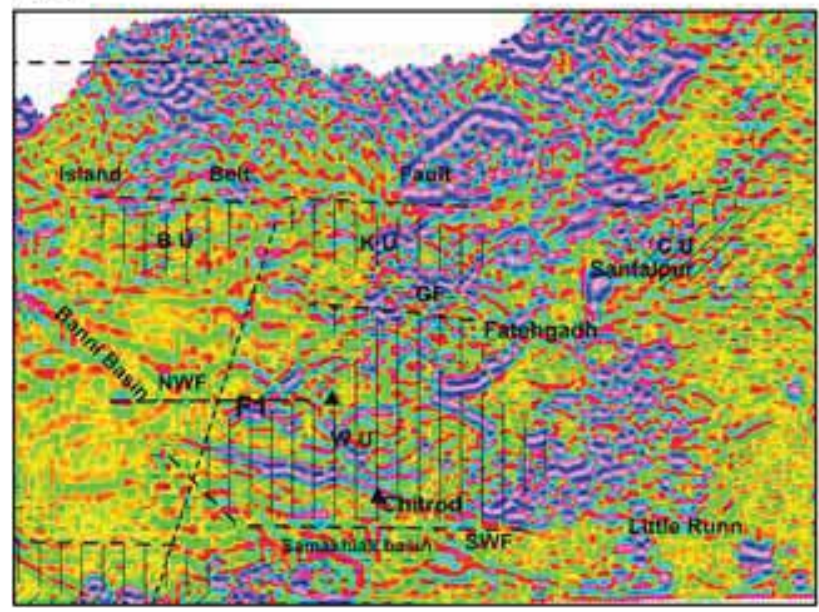

Figure 5. Results of the matched bandpass filtering applied to separate the anomalies from the different interfaces. (a) Magnetic signatures from the deepest layer at $4 \mathrm{~km}$. (b) Magnetic anomalies originating from the interface at $1.8 \mathrm{~km}$. (c) Magnetic anomalies related to sources from $1.08 \mathrm{~km}$ interface. Mapped faults and stratigraphic units from figure 1 are superposed on (c). Superposed white lines (a) represent the inferred lineaments from figure 7 . long wavelength anomalies seen in figure 5(a). The anomalies present at the shallowest layer at $1.08 \mathrm{~km}$ (figure 5c) primarily contain very shortwavelength, low-amplitude linear anomalies similar to the second vertical derivative map (figure 3) representing the signatures of dykes (Mallik et al. 2008), sills, intrusives, domal uplifts, etc., in the WU, that can possibly be associated with the later event in the formation of the basin. Anomalies comprising high amplitude and high frequency are less in the western half and the easternmost part of the map. In the Island Belt uplift region, many semi-circular alkaline gabbro-diorite plutonic complexes exist. Prominent gabbroic sills and dykes, which cut through the entire complexes, are present in the region (Ray et al. 2006; Paul et al. 2008; Sen et al. 2016) which is reflected as short wavelength anomalies in figures 3 and $5(\mathrm{c})$.

The depths calculated from the subset anomaly grid (by dividing the area into $20 \mathrm{~km} \times 20 \mathrm{~km}$ blocks with $50 \%$ overlap), provided average depth values of $2.3,1$ and $0.5 \mathrm{~km}$ suggesting three major interfaces. This is more or less in accordance with the depth calculated for the whole region which showed an additional interface at an average depth of $4 \mathrm{~km}$. From the depths calculated using the subset anomaly grids, histogram equalised image maps have been generated for the whole region depicting the depth to the three interfaces (figure $6 \mathrm{a}-\mathrm{c}$ ). The deepest interface is at an average depth of $2.3 \mathrm{~km}$ from the flying height of $300 \mathrm{~m}$. Seismic refraction studies along two profiles in this region (location shown in figure 6a) have shown that the basement is at an average depth of $2 \mathrm{~km}$ (Rajendra Prasad et al. 2010). Sediment thickness estimation using the Sp converted phase showed ranges of $1-1.5 \mathrm{~km}$ in the Wagad area and $\sim 2 \mathrm{~km}$ in the Banni basin (location of the broadband seismic stations used is shown in figure 6a) (Chopra et al. 2010). Hence, we interpret the deepest interface at an average depth of $2.3 \mathrm{~km}$ as representing the average depth to the basement. To have a better picture of the basin configuration and setting, the faults mapped at the surface along with F1 inferred from the present study have been superposed on these maps. The role of the major master faults (SWF, GF, IBF, etc.) in shaping the basement topography and controlling the sedimentary deposition is clearly evident from figure 6(a). A sudden change in basement depth can be observed from the Banni basin towards the WU area across the NE-SW striking F1 which also coincides with the western limit of the high 
(a)
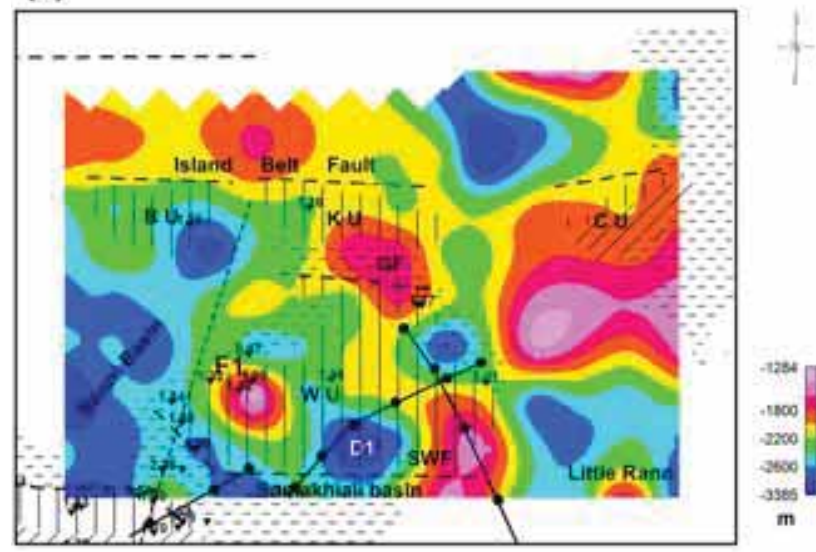

(b)

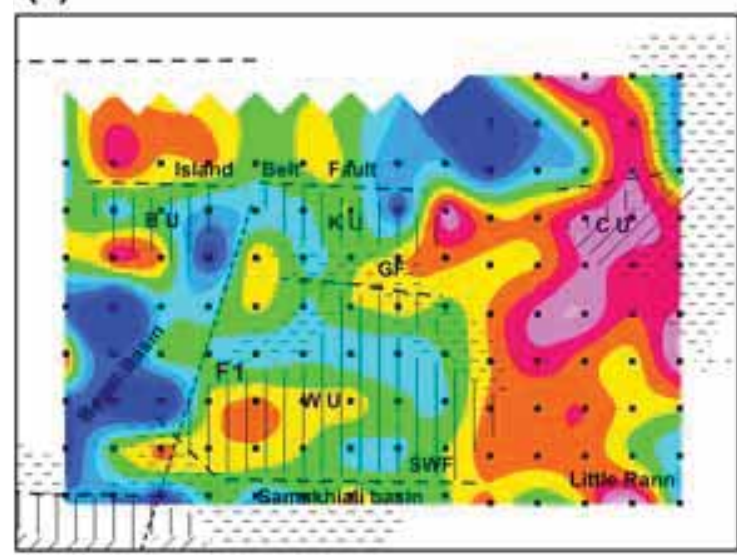

(c)
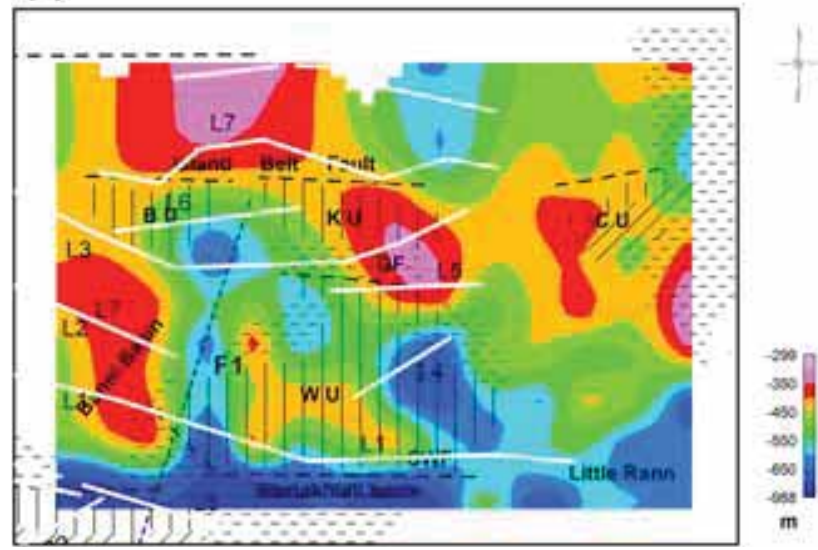

Figure 6. Depth to the interfaces calculated from the subset anomaly grids using radially averaged power spectrum. Geology map of the region and the mapped faults are superposed. (a) The deepest interface lying at an average depth of $2.3 \mathrm{~km}$. Black lines with black filled circles show the location of seismic refraction profile with shot points (Rajendra Prasad et al. 2010). Filled inverted triangles with numbers show locations of broad band seismic stations with sediment thickness (Chopra et al. 2010). Other abbreviations are as in figure 1. (b) The intermediate interface lying at an average depth of $1 \mathrm{~km}$. Black dots represent the location of the centres of the subset grids used for the calculation of radially averaged power spectrum. (c) The shallowest interface lying at an average depth of $500 \mathrm{~m}$. amplitude anomalies (figure 3). Fault F1, if extended further south-west, will pass through the epicentral region of the 2001 Bhuj earthquake. The basement depression within the Wagad region (D1) is previously modelled from gravity studies as a basin (Chandrasekhar et al. 2005) with average $2.3-\mathrm{km}$ thick sediments. The basement deepens south of the SWF within the Samakhiali basin. Relative to the Banni basin, the basement is at shallower levels below the Chorar and Bela uplifts and the region north of the IBF associated with highfrequency anomalies (figure 3). From figure 6(a), it appears that the region east of the WU, covered by recent alluvial sediments, the basement is at a very shallow level. The lateral variation of the second interface, at an average depth of $1 \mathrm{~km}$ from a survey height of $300 \mathrm{~m}$ above ground level, is represented in figure $6(\mathrm{~b})$. The continuation of the basement-related master faults is evident in this interface as well. The undulations of this interface more or less mimic the basement topography. Fault F1, previously interpreted as the eastern limit of the Banni basin, is traceable in the second interface also. The third and the shallowest interface at an average depth of $\sim 0.5 \mathrm{~km}$ also reflects the signatures of the master faults with basement depth varying on either side (figure 6c). But fault F1 does not show any signatures in this interface, meaning there is no depth variation on either side of $\mathrm{F} 1$.

The Kutch basin accommodates a stratigraphic succession ranging in age from Middle Jurassic to the Holocene (Biswas 2005; DGH dghindia.gov.in/). On the basis of outcrop and well data, the lithostratigraphy and the chronostratigraphy of the inland and offshore parts of the basin have been studied in detail by several workers (Biswas 1992, 1987, 2005; Octavian and Dave 2017). In the subsurface lithostratigraphic units, some of the sedimentary strata are composed of ferruginous sandstone/limestone which can contribute to magnetic anomalies if they have considerable thickness. To ascertain the age of the faults discussed above, we have made an attempt to correlate the magnetic interfaces obtained from power spectral computations with the stratigraphy of the region. From the information available from the well data and the seismic refraction studies, the basement of the Kutch Rift basin in the Banni basin, WU and adjoining regions lies nearly at $2.5 \mathrm{~km}$ depth. Hence the magnetic interface at an average depth of $2.3 \mathrm{~km}$ (this varies over Banni basin, WU, IBU) obtained from the power spectrum broadly represents the depth to the crystalline basement. The 
second interface at an average depth of $1.0 \mathrm{~km}$ may be reflecting the depth to the top of the bands of ferruginous sandstone associated with the lower part of the Wagad standstone within the WU area and Jhuran formation within the Banni basin. In the eastern Kutch region, the lithology of the Kharinadi formation of Lower Miocene age is characterised by red lateritic conglomerate often with agate pebbles, ferruginous sandstone and laminated claystone bands (DGH dghindia.gov.in/). The shallowest interface may be reflecting the signatures of ferruginous sandstones associated with the Kharinadi formation. In short, the shallowest and intermediate interfaces deduced from power spectral analysis, respectively, represent the ferruginous sandstone of Miocene Kharinadi formation and lower Cretaceous Jhuran/Wagad formation while the deeper interface reflects the undulations associated with the crystalline basement. As discussed previously, all the NW-SE and E-W trending master faults associated with the basement can be traced along all the three interfaces (as can be seen from the depths and the faults mapped in the surface in figure $6 \mathrm{a}-\mathrm{c}$ ) suggesting these faults have reactivated many times in the geological past. However, fault F1 does not show any signature in the shallowest interface, i.e., the Miocene Kharinadi formation which suggests that this fault might have formed prior to the deposition of Miocene sediments. At the same time a change in depth on either side of this fault can be seen in the Lower Cretaceous interface as well as the basement suggesting that this fault has formed post-Lower Cretaceous sedimentation.

\section{Identification of lineaments and correlation with geology}

To delineate the magnetic contacts/faults/lineaments present in these magnetic interfaces, we have applied the edge detection techniques discussed above. The final lineament map is prepared after comparing the results of all these methods. The HGM of the deeper layer reveals the signatures of the major basement-related faults and the intermediate layer shows the intra-sedimentary magnetic contrasts. The shallowest layer is excluded as it is of extremely complicated nature possibly representing small-scale fractures within the uppermost sedimentary units. Magnetic lineaments which have signatures in all the edge detection techniques only are considered for the generation of the lineament map of the region (figure 7). The lineaments present in all the three layers are represented in green colour. The major lineaments are trending in the $\mathrm{E}-\mathrm{W}$ direction in the WU area. In the western side, the lineaments have a trend of the NW-SE and changing to the NE-SW in the extreme east with EW in the centre. We can very well distinguish the variation in the trends and depths of the linear features present on both sides of the fault F1 (from Euler depths, figure 7 ). F1 roughly coincides with the location of the Lathi-Rajkot lineament (Bakliwal and Ramasamy 1987), under cover in the Kutch basin, interpreted as representing a probable fault in the Jurassic rocks. EW trending lineament L1 evident in the shallow (analytic signal) as well as deeper levels (HGM and Euler) coincides with the geologically mapped SWF. L1 can be traced within the Banni basin even though it does not show any signatures in the analytic signal map probably because of the thick sediments and downthrown by F1 within the Banni basin. As the expression of L1 is found to be extending from the west to the east and at all depth levels, this fault might have played a major role in the formation of the Kutch Rift basin. The north-westward extension of L2 and L3, respectively, coincides with the mapped NW-SE trending Goradonger (Ngangom and Thakkar 2016) and Kaladonger faults exposed in the Patcham islands. In addition to these mapped surface faults, several other lineaments (L4-L6), probably involving the basement, are observed in the region between the exposed SWF and IBF (L7). Lineament L7, coinciding with the IBF, expresses itself in both shallow and deeper levels and appears to be dislocated rather than a straight lineament. Further north of IBF, several lineaments trending NW-SE, EW and NE-SW can be observed suggesting that the area has undergone severe tectonic activity. This region is the shallowest as is evident from the depth to the basement map (figure 6a).

The major lineaments discussed above may be related to the tectonic history of the Kutch rift basin, and may represent faults, axial trace of regional folds and group/formational boundaries. The randomly oriented minor lineaments, maximum in number, with varying distribution, may represent expressions of faults, fractures, dykes and axial traces of large-scale folds. The NW-SE trend in the western region changing to the EW in the eastern region, probably involving the basement as well as intra-sedimentary layers, is the dominant trend in the inferred lineament map. This is in conformity with the structural features and the 


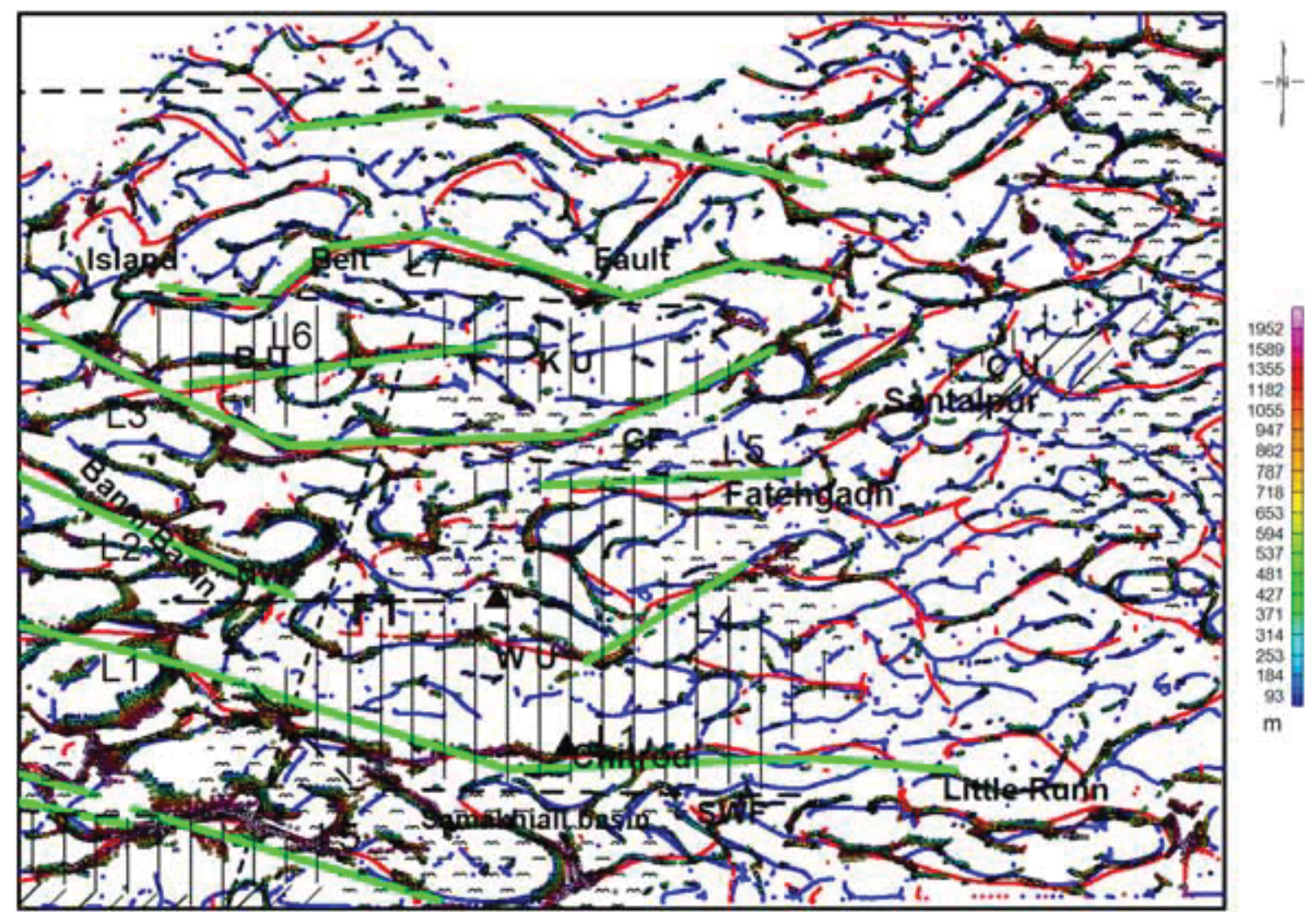

Figure 7. Interpreted lineament map. The green-coloured lines are the lineaments present in all the layers. Here we show peaks from the deepest interface $(4 \mathrm{~km})$ only. Coloured circles represent Euler deconvolution solutions computed assuming structural index 0 representing contacts and window length 10. Colour bar provides the depth to the top of the sources computed from Euler deconvolution. Red lines: HGM peaks from data upward continued to $5 \mathrm{~km}$, blue lines represent HGM peaks from deepest interface at average depth of $4 \mathrm{~km}$. Black star represent the 2001 Bhuj earthquake epicentre. Mapped faults from figure 1 are superposed to show the commonality and the new one that was interpreted from the present analysis. Most of the newly identified lineaments are in the subsurface.

trend that resulted from the tectonic deformation causing rifting in the Kutch basin. The most dominant trend (NW-SE) observed in many parts of the study area has been suggested to be intimately associated with the stress history that has existed since the early Pre-Cambrian. The observed correlation between the locations of the basement and intra-sedimentary faults, at places, strongly suggests a tectonic link between the basement and the overlying sedimentary column suggesting the reactivation of these faults at different periods during the evolution of the basin. This continued process of reactivation and propagation might have given rise to additional set of faults and fractures (mapped minor lineaments) due to the local structural and tectonic disturbances. The general consistency in orientations among the Pre-Cambrian basement faults, the lineaments interpreted from aeromagnetic data, and the previously mapped surface faults indicates that the systematic fault system at basement in the area probably have been reactivated many times and thus have connectivity upward perhaps all the way to the surface (Radhika et al. 2017). Thus the Kutch rift basin has a complicated tectonic regime which is caused either by its formation mechanism or significant tectonic activities that occurred later.

\section{A possible evolutionary model}

The present study gave additional inputs to the current understanding that the NW-SE to EW trending ridges and depressions in the Kutch rift basin were formed due to the rifting of the Indian and African plates in the Late Triassic to Early Jurassic era along the Delhi-Aravalli Pre-Cambrian trend (Biswas 1987, 2005). The signatures of this rifting stage can be observed as NW-SE to $\mathrm{E}-\mathrm{W}$ trending long wavelength anomalies in the deeper layers. The horizontal gradient magnitude showing the deeper signatures reveal the major lineaments as mainly trending in the $\mathrm{E}-\mathrm{W}$ 
direction. It has also been seen that these primary trends associated with the ridges and depressions are at several places dislocated or truncated by younger NNE-SSW to NE-SW lineaments possibly representing basement-related faults. Several anomalies within the zone bounded by these transverse faults show the NE-SW elongation. One such fault is F1 that delimits the uplifted Wagad block with respect to the Banni basin. During the north-eastward movement, the Indian plate has moved over the Reunion hotspot during which the intrusions rose upwards through the faults/fractures in the basement causing doming and uplift (Maurya et al. 2017). This doming and uplift might have given rise to NNE-SSW to NE-SW trending transverse faults due to which the Mesozoic sequences deposited in the ridges and depression have undergone block faulting. The master faults might have acted as pathways for the upwelling magma. The magnetic signatures of linear anomalies related to dykes and 3D anomalies representing intrusions are the indicators of the Deccan trap activity as these have close proximity to the master faults. From the generated depth to the basement map, it was shown that the basement and the Lower Cretaceous sediments on either side of fault F1 are at different depth levels whereas this fault has not affected the Miocene formation suggesting that this fault might have resulted from the upwelling and doming related to magmatic activity associated with the Deccan trap volcanism. Palaeomagnetic studies of the flows/intrusives/plugs from the Kutch Mainland, WU, etc., have shown pole position contemporaneous to the Deccan Super pole (Narasimhan et al. 2008; Paul et al. 2008) thus supporting the above observation. The rifting ceased during this period of time and the movement of Indian plate towards the north eventually resulted in the collision with the Eurasian plate. In response to this collision, which occurred during the early Eocene, horizontal strain started to accumulate in the basin and caused the inversion. The structural inversion triggered the reactivation of the primary normal faults and the transverse faults formed during the magmatic activity (Maurya et al. 2017) associated with the passage over Reunion hotspot. Due to the N-S compression, the domal uplifts formed during the magmatic activity got deformed and elongated in the E-W direction which caused the overprinting in the magnetic anomalies. The current architecture of the Kutch rift basin is the result of the combined effect of these stages of evolution.

\section{Conclusion}

In the present study we have analysed the aeromagnetic data for mapping the magnetic lineaments present along the WU and adjoining regions at different depth levels and to recognise the propagation of these features through the sedimentary layer. The aeromagnetic anomaly map depicts several major E-W, NE-SW and NW-SE oriented lineaments/faults, which represent the structural trends associated with different stages of evolution of this rift basin. The estimation of the mean depth to the magnetic interfaces is accomplished through the analysis of radially averaged power spectrum of the DRTP magnetic data. Four magnetic interfaces were delineated from the 1D power spectra with the shallowest interface at roughly $500 \mathrm{~m}$ and the deepest at $\sim 4 \mathrm{~km}$. Matched bandpass filtering was applied to the DRTP map for isolating and enhancing the magnetic anomalies present within these magnetic interfaces. To delineate the magnetic contacts, faults and lineaments present in these interfaces, we have applied different edge detection techniques. As the study area has diverse stratigraphic and structural characteristics, the response of the radially averaged power spectrum was computed from the same-size subsets of the DRTP grid. The analysis suggests that the western side consisting of the Banni plain is deeper than the eastern region. WU and the region above the Gedi fault show shallower depths, indicating that they may be related to the basement-related uplifts. The presence of a major fault trending NE-SW, passing through the Bhuj earthquake epicentre, is very well demarcated from this map. This fault appears to form the eastern boundary fault of the Banni basin. Based on the results from the aeromagnetic data analysis and other published data, we made an attempt to generate a two-stage evolutionary model for the study region. The first stage includes the extension and rifting which occurred in the $\mathrm{N}-\mathrm{S}$ direction creating the $\mathrm{E}-\mathrm{W}$ trending major faults. The NW-SE to E-W trending ridges and depressions are formed due to this rifting which occurred in the Late Triassic to the early Jurassic. The indication of this rifting stage can be observed as NW-SE to E-W trending long wavelength anomalies in the deeper layers. Before the second stage, i.e., the compression and structural inversion phase, the Deccan volcanic event occurred when the Indian plate passed over the Reunion 
hotspot. During this process, the Mesozoic sequences were uplifted and structural domes were formed due to the magma intruding into these formations. New faults like the F1 might have formed during this period during the doming as a result of magma upwelling. The indications of the Deccan trap activity could be observed in the intermediate magnetic interfaces. The rifting was terminated eventually and the Indian plate collided with the Eurasian plate which caused the inversion phase of the basin. Due to the N-S compression caused by the collision, the uplifts created by the magmatic activity started to elongate in the $\mathrm{E}-\mathrm{W}$ direction.

\section{Acknowledgements}

The authors thank the Director, Indian Institute of Geomagnetism, Mumbai, for his constant encouragement and support and for the permission to publish this work. Funds for carrying out this research at the Indian Institute of Geomagnetism were provided by the Department of Science and Technology (DST), Government of India, New Delhi. The authors thank the two anonymous reviewers and the editorin-chief whose suggestions and comments helped improve the quality of the manuscript.

\section{References}

Alagbe O A 2015 Depth estimation from aeromagnetic data of Kam; Int. J. Adv. Res. Phys. Sci. 2 37-52.

Anand S P and Rajaram M 2007 Aeromagnetic signatures of the cratons and mobile belts over India; Int. Assoc. Gondwana Res. Mem. 10 233-242.

Ansari A and Alamdar K 2009 Reduction to the pole of magnetic anomalies using analytic signal; World Appl. Sci. J. 7 405-409.

Arkani-Hamed J 2007 Differential reduction to the pole: Revisited; Geophysics 72 13-20.

Bakliwal P C and Ramasamy S M 1987 Lineament fabric of Rajasthan and Gujarat, India; Rec. Geol. Surv. India 113 54-64.

Biswas S K 1987 Regional tectonic framework, structure and evolution of the western marginal basins of India; Tectonophys. 135 307-327.

Biswas S K 1992 Tertiary stratigraphy of Kutch; J. Palaeontol. Soc. India 37 1-29.

Biswas S K 1999 A review on the evolution of rift basins in India during Gondwana with special reference to western Indian basins and their hydrocarbon prospects; Proc. Indian Natl. Sci. Acad. Spec. Issue 65 261-283.

Biswas S K 2005 A review of structure and tectonics of Kutch basin, western India, with special reference to earthquakes; Curr. Sci. 88 10-25.
Biswas S K and Khattri K N 2002 A geological study of earthquakes in Kutch, Gujarat, India; J. Geol. Soc. India 60 131-142.

Blakely R J 1995a Potential Theory in Gravity and Magnetic Applications; Cambridge University Press, Cambridge, Chapter 12, pp. 324-328.

Blakely R J 1995b Potential Theory in Gravity and Magnetic Applications; Cambridge University Press, Chapter 11, pp. 300-308.

Chandrasekhar D V and Mishra D C 2002 Some geodynamic aspects of Kutch basin and seismicity: An insight from gravity studies; Curr. Sci. $\mathbf{8 3}$ 492-498.

Chandrasekhar D V, Sing B, Md. Firozishah and Mishra D C 2005 Analysis of gravity and magnetic anomalies of Kachchh rift basin, India and its comparison with the New Madrid seismic zone, USA; Curr. Sci. 88 1601-1608.

Chopra S, Rao K M and Rastogi B K 2010 Estimation of sedimentary thickness in Kachchh basin, Gujarat using S P converted phase; Pure Appl. Geophys. 167 1247-1257.

Chowksey V, Maurya D M, Khonde N and Chamyal L S 2010 Tectonic geomorphology and evidence for active tilting of the Bela, Khadir and Bhanjada islands in the seismically active Kachchh palaeorift graben, Western India; Z. Geomorphol. 54 467-490.

Chowksey V, Maurya D M, Joshi P, Khonde N, Das A and Chamyal L S 2011 Lithostratigraphic development and neotectonic significance of the quaternary sediments along the Kachchh Mainland fault (KMF) zone, Western India; $J$. Earth Syst. Sci. 120 979-999.

Cooper G R J and Cowan D R 2005 Differential reduction to the pole; Comput. Geosci. 31 989-999.

Cowan D R and Cowan S 1993 Separation filtering applied to aeromagnetic data; Explor. Geophys. 24 429-436.

DGH- http://dghindia.gov.in/

Geological Survey of India (GSI) 2001 Seismo Tectonic Atlas of India and its Environs (Scale 1:1,000,000); Special Publication Series, 59, Geological Survey of India, Bangalore.

Grauch V J S, Hudson M R, Minor S A and Caine J S 2006 Sources of along-strike variation in magnetic anomalies related to intrasedimentary faults: A case study from the Rio Grande Rift, USA; Explor. Geophys. 37 372-378.

Karanth R V and Gadhavi M S 2007 Structural intricacies: Emergent thrusts and blind thrusts of Central Kachchh, western India; Curr. Sci. 93 1271-1280.

Kothyari G C, Dumka R K, Singh A P, Chauhan G, Thakkar M G and Biswas S K 2016a Tectonic evolution and stress pattern of South Wagad fault at the Kachchh rift basin in Western India; Geol. Mag. 154(4) 875-887.

Kothyari G C, Rastogi B K, Morthekai P and Dumka R K 2016b Landform development in a zone of active Gedi Fault, Eastern Kachchh rift basin, India; Tectonophysics $670115-126$.

MacLeod I N, Jones K and Dai T F 1993 3-D analytic signal in the interpretation of total magnetic field data at low magnetic latitudes; Explor. Geophys. 24 679-688.

Malik J N, Gadhavi M S, Kothyari G C and Sravanthi S 2017 Paleo-earthquake signatures from the South Wagad Fault (SWF), Wagad Island, Kachchh, Gujarat, western India: A potential seismic hazard; J. Struct. Geol. 95 142-159.

Mallik J, Mathew G, Angerer T and Greiling R O 2008 Determination of directions of horizontal principal stress 
and identification of active faults in Kachchh (India) by electromagnetic radiation (EMR); J. Geodyn. 45 234-245.

Mandal P, Kumar N, Sathyamurthy C and Raju I P 2009 Ground-motion attenuation relation from strong-motion records of the $2001 \mathrm{Mw} 7.7$ Bhuj earthquake sequence (2001-2006), Gujarat, India; Pure Appl. Geophys. 166 1-9.

Mathew G, Singhvi A K and Karanth R V 2006 Luminescence chronometry and geomorphic evidence of active fold growth along the Kachchh Mainland Fault (KMF), Kachchh, India: Seismotectonic implications; Tectonophys. 422 71-87.

Maurya D M, Chouksey V, Joshi P N and Chamyal L S 2013a Application of GPR for delineating the neotectonic setting and shallow subsurface nature of the seismically active Gedi fault, Kachchh, western India; J. Geophys. Eng. 10 1-12.

Maurya D M, Khonde N, Das A, Chowksey V and Chamayal L S 2013b Subsurface sediment characteristics of the Great Rann of Kachchh, western India based on preliminary evaluation of textural analysis of two continuous sediment cores; Curr. Sci. 104 1071-1077.

Maurya D M, Chouksey V, Patidar A K and Chamyal L S 2017 A review and new data on neotectonic evolution of active faults in the Kachchh Basin, Western India: Legacy of post-Deccan trap tectonic inversion; Geol. Soc. London, Spec. Publ. 445 237-268.

Milligan P and Gunn P J 1997 Enhancement and presentation of airborne geophysical data; AGSO J. Aust. Geol. Geophys. 17 63-75.

Mishra D and Biswas S K 2009 Sedimentology, sequence stratigraphy and syn-rift model of younger part of Washtawa Formation and early part of Kanthkot Formation, Wagad, Kachchh Basin, Gujarat; J. Geol. Soc. India 73 519-527.

Narasimhan C L, Patil S K and Arora B R 2008 A paleomagnetic perspective on the flows and intrusives of the Kutch Rift basin and its implications on the Reunion Plume-Indian plate interaction; In: Indian dykes: Geochemistry, geophysics, geochronology (eds) R K Srivastava, C Shivaji and N V Chalapathi Rao, Narosa Publ. House Pvt. Ltd, New Delhi, pp. 159-179.

Ndougsa-Mbarga T, Feumoe A N S, Manguelle-Dicoum E and Fairhead J D 2012 Aeromagnetic data interpretation to locate buried faults in South-East Cameroon; Geophysica 48 49-63.

Ngangom M and Thakkar M G 2016 Morphometric characterization and neotectonic evolution of island belt uplift of Kachchh, Western India; Spec. Publ. Geol. Soc. India 6 151-167.

Ngoh J D, Mbarga T N, Assembe S P, Meying A, Owono O U and Tabod T C 2017 Evidence of structural facts inferred from aeromagnetic data analysis over the Guider-Maroua Area (Northern Cameroon); Int. J. Geosci. 8 781-800.

Octavian C and Dave A 2017 Cenozoic sequence stratigraphy of the Kachchh Basin, India; Mar. Pet. Geol. 86 1106-1132.

Paul D K, Ray A, Das B, Patil S K and Biswas S K 2008 Petrology, geochemistry and paleomagnetism of the earliest magmatic rocks of Deccan Volcanic Province, Kutch, Northwest India; Lithos 102 237-259.

Peters L J 1949 The direct approach to magnetic interpretation and its practical application; Geophysics 14 290-320.
Phillips J D 2000 Locating magnetic contacts - A comparison of the horizontal gradient, analytic signal, and local wavenumber methods; In: Society of exploration geophysicists technical program expanded abstracts, 70th Annual meeting, Vol. 19, pp. 402-405.

Phillips J D, Hansen R O and Blakely R J 2007 The use of curvature in potential field interpretation; Explor. Geophys. 38 111-119.

Radhika P R, Anand S P and Rajaram M 2017 Structural mapping of Kutch Rift Basin from aeromagnetic data; $J$. Geophys. XXXVIII(3) 187-197.

Rajaram M and Anand S P 2014 Aeromagnetic signatures of Precambrian shield and suture zones of Peninsular India; Geosci. Front. 5 3-15.

Rajaram M, Anand S P and Balakrishna T S 2006 Composite magnetic anomaly map of India and its contiguous regions; J. Geol. Soc. India 68 569-576.

Rajendra Prasad B, Wenkateswarlu N, Prasad A S S S R S, Murthy T and Sateesh S 2010 Basement configuration of on-land Kutch basin from seismic refraction studies and modeling of first arrival travel time skips; J. Asian Earth Sci. 39 460-469.

Ray A, Patil S K, Paul D K, Biswas S K, Das B and Pant N C 2006 Petrology, geochemistry and magnetic properties of Sadara sill: Evidence of rift related magmatism from Kutch basin, northwest India; J. Asian Earth Sci. 27 907-921.

Reid A B, Allsop J M, Granser H, Millet A J and Somerton I W 1990 Magnetic interpretation in three dimensions using Euler deconvolution; Geophysics 55 80-91.

Roest W R, Verhoef J and Pilkington M 1992 Magnetic interpretation using the 3-D analytic signal; Geophysics $\mathbf{5 7}$ 116-125.

Sant D A, Parvez I A, Rangarajan G, Patel S J, Bhatt M N and Sanoop Salam T A 2017 Subsurface profiling along Banni Plains and bounding faults, Kachchh, Western India using microtremors method; J. Asian Earth Sci. 146 326-336.

Sen G, Hames W E, Paul D K, Biswas S K, Ray A and Sen I S 2016 Pre-Deccan and Deccan Magmatism in Kutch, India: Implications of new 40Ar/39Ar ages of intrusions; Spec. Publ. Geol. Soc. India 6 211-222.

Sheriff S D 2010 Matched filter separation of magnetic anomalies caused by scattered surface debris at archaeological sites; Near Surf. Geophys. 8 145-150.

Singh V P and Singh R P 2005 Changes in stress pattern around epicentral region of Bhuj earthquake of 26 January 2001; Geophys. Res. Lett. 32 1-4.

Singh A P, Shukla A, Kumar M R and Thakkar M G 2017 Characterizing surface geology, liquefaction potential, and maximum intensity in the Kachchh seismic zone, western India, through microtremor analysis; Bull. Seismol. Soc. Am. 107 1277-1292.

Spector A and Grant F S 1970 Statistical model for interpreting aeromagnetic data; Geophysics 35 293-302.

Telford W M, Geldart L P and Sheriff R E 1990 Applied geophysics (2nd edn); Cambridge University press, New York, chapter 2, 32p.

Thomas A E 1951 The second derivative method of gravity interpretation; Geophysics 16 29-50.vv 